\title{
Orchidopexy Results in the Recovery of Sperm in the Ejaculate of a Non-obstructive Azoospermic Adult with Bilateral Cryptorchidism - A Case Report
}

\author{
Huy Quang Duong ${ }^{1, \star}$, Van Kim Hoang Tang ${ }^{2}$, Georgios Liperis ${ }^{3}$, Le Dang Khoa ${ }^{4}$ \\ ${ }^{1}$ Department of Andrology, Au Co Hospital, Bien Hoa City, Vietnam \\ ${ }^{2}$ Infertility Department, Hung Vuong Hospital, HCMC, Vietnam \\ ${ }^{3}$ Westmead Fertility Centre, Institute of Reproductive Medicine, University of Sydney, Westmead, NSW 2145, Australia \\ ${ }^{4}$ IVFMD, My Duc Hospital, Ho Chi Minh City, Vietnam
}

\begin{abstract}
Cryptorchidism or undescended testis is one of the most common pediatric disorders of the male endocrine glands and the most typical congenital abnormality identified at birth. Bilateral cryptorchidism is frequently associated with azoospermia and male infertility. The standard therapy is the surgical repositioning of the testes (orchidopexy) within the scrotal sac after the age of six months to eighteen months. Current findings suggest that no sperm is recovered in the ejaculate, for patients with bilateral cryptorchidism, when the mean age at the time of orchidopexy is around 16 years and above. Here we report an unusual case of an adult patient with bilateral cryptorchidism and non-obstructive azoospermia for which orchidopexy resulted in the recovery of sperm in the ejaculate, improving his options for future fertility treatment.
\end{abstract}

Keywords: Cryptorchidism; Azoospermia; Orchidopexy; Spermatogenesis.

\section{TÓM TẮT}

(ABSTRACT IN VIETNAMESE)

Tinh hoàn ẩn hay tinh hoàn không xuống bìu là một trong những dị tật nhi khoa phổ biến nhất của tuyến sinh dục nam và là một trong các bất thường bẩm sinh điển hình nhất có thể phát hiện lúc sanh. Tinh hoàn ẩn 2 bên thường có liên quan đến tình trạng không có tinh trùng ở nam giới khám vô sinh. Điều trị chuẩn trong bệnh lý này là đưa 2 tinh hoàn đặt trong túi da bìu (hạ tinh hoàn ẩn) trong độ tuổi từ sáu đến mười tám tháng sau sanh. Tra cứu y văn cho thấy không có trường hợp nào tinh hoàn ẩn 2 bên được hồi phục có tinh trùng trong tinh dịch nếu can thiệp phẫu thuật sau 16 tuổi. Ở đây, chúng tôi báo cáo một trường hợp hiếm gặp ở nam giới trưởng thành với tinh hoàn ẩn hai bên và vô tinh không do bế tắc, với kết quả hồi phục có tinh trùng trong tinh dịch sau can thiệp hạ tinh hoàn ẩn và giúp gia tăng cơ hội lựa chọn cách điều trị sinh sản trong tương lai.

Tù khóa: Tinh hoàn ẩn; không tinh trùng; hạ tinh hoàn ẩn; quá trình sinh tinh.

\section{INTRODUCTION}

Cryptorchidism is a common cause of male infertility, with a prevalence of $1 \%$ in adults, 3-8\% in infertile men and $20 \%$ in men with azoospermia (Lee and Coughlin, 2001). The incidence of azoospermia in unilateral cryptorchidism is $13 \%$ and it reaches $89 \%$ in untreated bilateral cryptorchidism (Hadziselimovic and Herzog, 2001). The degeneration of germ cells in undescended testes is apparent after the first year of life and varies, depending on the location of the testes. During the second year of life, the germ cell population declines (Gracia et al., 1995). Early treatment is therefore recommended (surgery should be performed from 6 months onwards and up until eighteen months) to conserve spermatogenesis and hormone production, as well as to decrease the risk of testicular cancer (Hadziselimovic et al., 2007). In adult patients, due to the depletion of germ cells, orchidopexy is usually performed for cosmetic reasons and for reducing the risk of testicular cancer. Current literature suggests that there is no sperm when the correction of bilateral cryptorchidism takes place around 16 years of age and above (Vernaeve et al., 2004; Stuart et al., 2003). Here, we report an unusual case of an adult patient with non-obstructive azoospermia (NOA) for whom spermatogenesis recovers following bilateral orchidopexy.

\section{CASE REPORT}

A 26-year-old man was hospitalized for the absence of both testes in the scrotum (Fig. 3A). Physical examination revealed a fit healthy

(c) 2019 by the Asia Pacific Initiative on Reproduction (ASPIRE) and World Scientific Publishing Co. Pte. Ltd. 2 Open Access article under the CC BY-NC-ND license (http://creativecommons.org/licenses/by-nc-nd/4.0/).

Received 31 January 2019; Accepted 3 February 2019; Published 25 February 2019

${ }^{*}$ Correspondence should be addressed to: Dr. Huy Quang Duong, Department of Andrology, Au Co Hospital, 47/19A, Dieu Xien street, 5B town, Tan Bien ward, Bien Hoa City, Dong Nai Province, Vietnam. Email: duongquanghuy1101@gmail.com 
Fig. 1. (A) Left testis. (B) Right testis. (C) Both testes located in the scrotum.

(A)

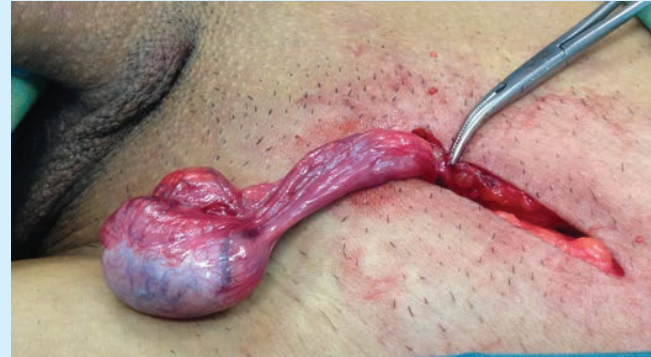

(B)

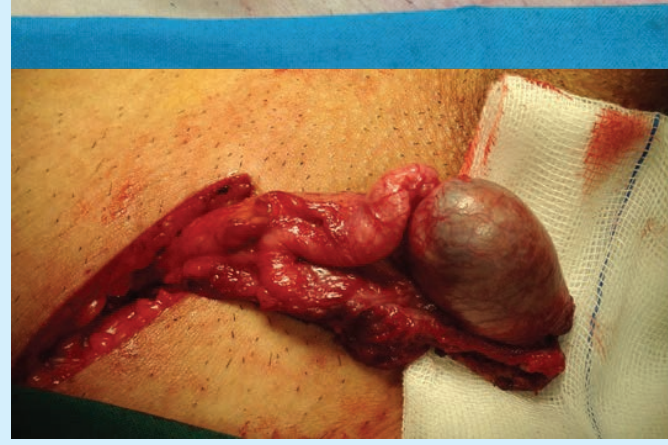

(C)

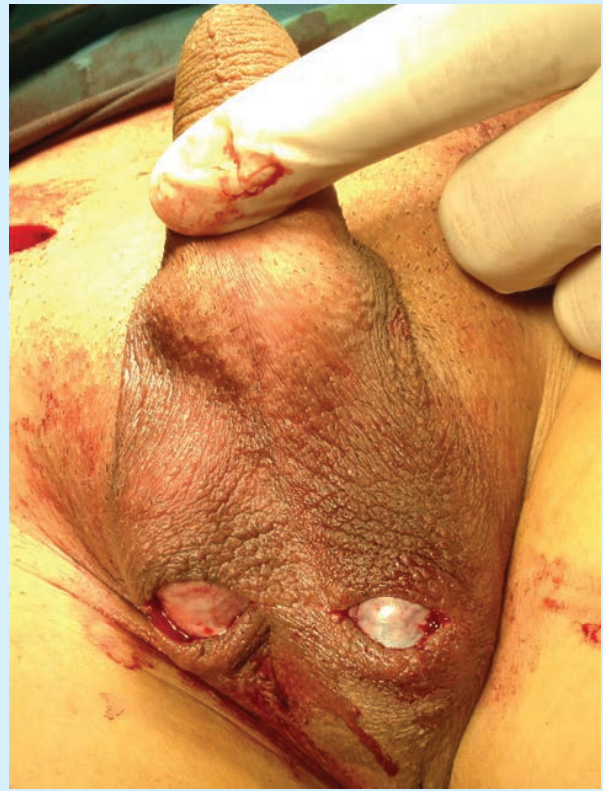

Fig. 2. (A) Left testis. (B) Right testis. Sertoli cells only syndrome in both testes.
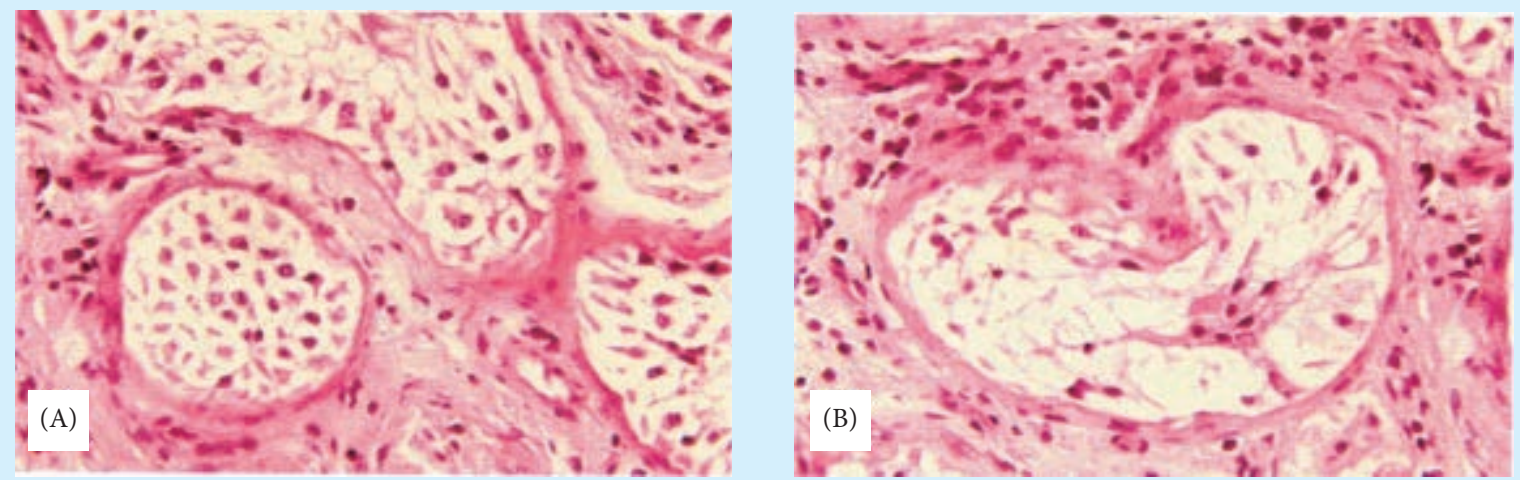

man with normal secondary sexual characteristics. The right testis could be palpable in the inguinal region, while the left could not. No sperm was seen in two semen analyses. Ultrasound showed that the right testis was located in the right inguinal canal, with the testis appearing to be normal and homogeneous with dimensions of $41 \times$ $21 \times 25 \mathrm{~mm}$ and having reduced distribution of color on the Doppler signal. The left testis was positioned higher to the internal inguinal ring, intra-abdominally, with the testis appearing to be homogeneous with dimensions of $33 \times 22 \times 25 \mathrm{~mm}$ and having reduced distribution of color on the Doppler signal. Markers of testicular cancer (e.g. $\mathrm{LDH}$, beta-hCG, AFP) were found to be in normal range.

Repair surgery was conducted to move the testes from the abdominal or inguinal area into the scrotum. The Stephen-Fowler technique was applied to the left testis due to short spermatic vessels (Fig. 1A). In contrary, the right testis needed to be placed down the scrotum while preserving blood vessels (Fig. 1B). Both of testes were situated in the scrotum at the end of surgery (Fig. 1C). Sertoli cell only syndrome (SCOS) was observed in both testes following histological examinations (Fig. 2).

Since the patient was single, semen analysis was repeated post-surgically every 2 months. Two months postoperatively, semen analysis showed cryptozoospermia. After six months, the concentration of ejaculated spermatozoa was $2 \times 10^{6}$ out of which $2 \%$ showed progressive motility, $3 \%$ non-progressive motility and $95 \%$ were immotile. Then, the ejaculated sperm was cooled in liquid nitrogen vapor by the conventional freezing method and stored in a cryotank for fertility preservation.

\section{DISCUSSION}

Before the advances of intracytoplasmic sperm injection (ICSI) and microsurgery, the options for NOA patients with cryptorchidism to conceive were limited to donor insemination. However, orchidopexy gave these men the opportunity of using assisted reproductive techniques with sperm retrieved from their own testes. Multiple techniques for sperm retrieval have been described in the literature including fine needle aspiration (FNA), percutaneous testis biopsy, open testicular biopsy or testicular sperm extraction (TESE) and microdissection TESE (micro-TESE). The use of the micro-TESE technique has a $50 \%$ success rate in retrieving sperm in these type of patients (Dabaja and Schlegel, 2013). Even in severe cases of congenital or acquired testicular failure, including cryptorchidism, post-chemotherapy, Klinefelter syndrome or azoospermia factor 
Fig. 3. (A) Before surgery. (B) After 6 months.

(A)

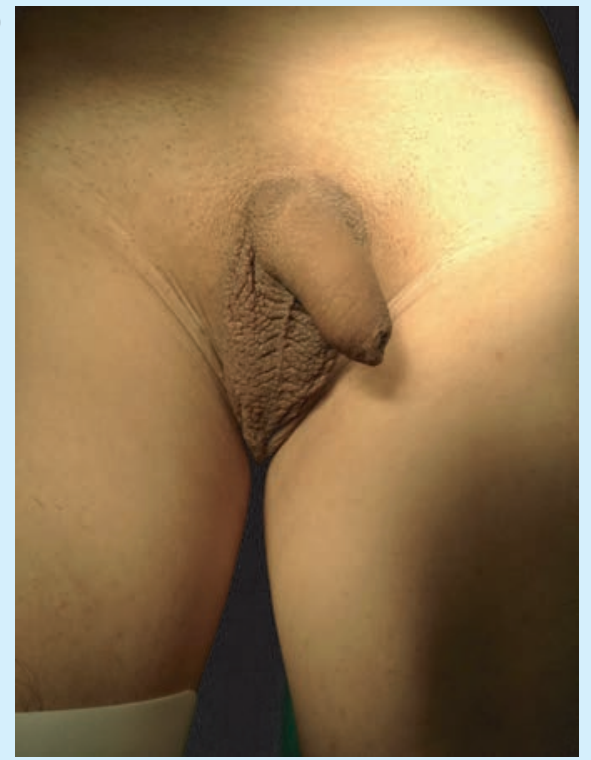

(B)

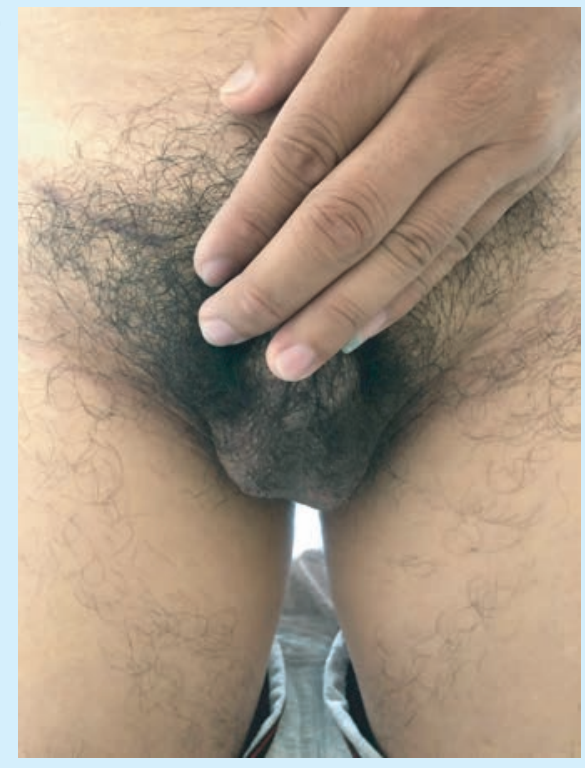

Table 1. Characteristics of NOA patients for which ejaculated spermatozoa were obtained following bilateral orchidopexy.

\begin{tabular}{|c|c|c|c|c|c|c|c|c|}
\hline \multirow[b]{2}{*}{ Author/year } & \multirow[b]{2}{*}{ Case } & \multirow[b]{2}{*}{ Age } & \multicolumn{2}{|c|}{ Preoperative } & \multirow[b]{2}{*}{ Operation } & \multirow[b]{2}{*}{ Biopsy } & \multicolumn{2}{|c|}{ Postoperative } \\
\hline & & & Location of UT, left/right & Semen analysis & & & Sperm count & Freezing \\
\hline Heaton 1993 & 1 & 23 & $\begin{array}{c}\text { Inguinal/ } \\
\text { Inguinal }\end{array}$ & Azoo & $\begin{array}{c}\text { Bilateral } \\
\text { orchidopexy }\end{array}$ & None & $\begin{array}{c}\text { a few } \\
\text { spermatozoa }\end{array}$ & None \\
\hline Shin 1997 & 1 & 23 & $\begin{array}{l}\text { Inguinal/ } \\
\text { Inguinal }\end{array}$ & Azoo & $\begin{array}{l}\text { Bilateral } \\
\text { orchidopexy }\end{array}$ & None & $7.6 \times 10^{6}$ & None \\
\hline Our Study 2018 & 1 & 26 & $\begin{array}{l}\text { Abdominal/ } \\
\text { Inguinal }\end{array}$ & Azoo & $\begin{array}{c}\text { Bilateral } \\
\text { orchidopexy }\end{array}$ & $\begin{array}{l}\text { Sertoli/ } \\
\text { Sertoli }\end{array}$ & $2 \times 10^{6}$ & Done \\
\hline
\end{tabular}

$c(A Z F c)$ deletion, sperm has been found and pregnancy and live births have been achieved (Dabaja and Schlegel, 2013). However, in order to perform micro-TESE in NOA men with bilateral cryptorchidism, the prerequisite is that the testes should be in the scrotum. Therefore, reposition of testes is mandatory. Even when, semen analyses post-orchidopexy results in azoospermia, the patient still has a $64 \%$ chance of finding sperm by micro-TESE (Dabaja and Schlegel, 2013). Therefore, even if orchidopexy does not result in the recovery of sperm from the ejaculate, conducting micro-TESE can be beneficial in order to recover sperm.

It is well known that cryptorchidism is associated with a high testicular temperature which is also thought to be the primary pathophysiologic feature of varicocele (Pastuszak and Wang, 2015). While microsurgical varicocelectomy demonstrated return of sperm to the ejaculate in $21-56 \%$ of azoospermic men with palpable varicoceles there are few that believe that orchidopexy can help recover the spermatogenesis in NOA patients (Pastuszak and Wang, 2015). A retrospective review of data from 4 geographically separate sites (2 U.S., 1 Egyptian, 1 European) showed that no patient with bilateral cryptorchidism had sperm in the ejaculate when corrected after 13 years of age (Stuart et al., 2003). In contrast, two reports have documented sperm recovery in the ejaculate after bilateral adult orchidopexy (Table 1). In 1993, an azoospermic male had sperm in semen after three months of bilateral orchidopexy and had three children in the next 6 years without any fertility treatment (Heaton et al., 1993). The second case recorded in 1997, had ejaculated spermatozoa after 12 months of bilateral orchidopexy and underwent fertility treatment with intracytoplasmic sperm injection using sperm obtained from his ejaculate (Shin et al., 1997). Both patients were operated at 23 years of age and the testicles were palpable in the groin. They were both married and willing to participate in fertility treatment. In our study, the patient was 26-year-old and single. Following the recovery of ejaculated sperm, semen freezing had been carried out. Moreover, biopsy of both testes provided us with additional information in regards to cancer development and enhances the fertility options of the patients by the retrieval of additional sperm by conducting microTESE, something that was not done in the previous 2 studies. This is the oldest patient with bilateral cryptorchidism recorded in the literature, for which, orchidopexy has resulted in the recovery of sperm in the ejaculate. This provides hope and options for other patients.

Cryptorchidism is a risk factor for testicular cancer and is associated with testicular microcalcification and intratubular germ cell neoplasia of unclassified type (ITGCNU); formerly carcinoma in situ (CIS) of the testes. According to the European Association of Urology (EAU) 2016, at the time of orchidopexy, performed in adulthood, testicular biopsy for detection of ITGCNU is recommended (Jungwirth et al., 2016). In this case, histological examinations post-surgically showed SCOS, while the previous studies in which sperm was found in the ejaculate did not include histology results (Heaton et al., 1993; Shin et al., 
1997). Although the biopsy result is benign for cancer, the patient is still instructed to self-examine that both testes are retained in the scrotum (Fig. 3B).

Sperm freezing was performed for our patient as soon as sperm was recovered. Sperm freezing is particularly important to preserve male fertility and guarantee the availability of sperm for fertility treatment. Especially for a single patient as the one in our study, risk factors such as testicular cancer and spermatogenesis arrest retain. Therefore, banking sperm as soon as it appears in the ejaculate post-operatively following bilateral orchidopexy, regardless of the technique used is highly recommended. Post-operatively recovered cryopreserved sperm can be used for fertility treatment with intracytoplasmic sperm injection (ICSI).

\section{CONCLUSION}

Orchidopexy might lead to spermatogenesis recovery providing hope for adult NOA patients with bilateral cryptorchidism. Fertility preservation is essential if sperm is found post-surgically.

\section{REFERENCES}

Dabaja AA, Schlegel PN. Microdissection testicular sperm extraction: An update. Asian J Androl. 2013;15(1):35-9.

Gracia J, et al. Clinical and anatomopathological study of 2000 cryptorchid testes. Br J Urol. 1995;75:697-701.

Hadziselimovic F, et al. Infertility in cryptorchidism is linked to the stage of germ cell development at orchidopexy. Horm Res. 2007;68:46-52.
Hadziselimovic F, Herzog B. The importance of both and early orchidopexy and germ cell maturation for fertility. Lancet. 2001; 358:1156-7.

Heaton ND, Davenport M, Pryor JP. Fertility after correction of bilateral undescended testes at the age of 23 years. Br J Urol. 1993; 71:490-1.

Jungwirth A, Diemer T, Kopa Z, Krausz C, Minhas S, Tournaye H. European Association of Urology Guidelines on Male Infertility. 2016.

Lee PA, Coughlin MT. Fertility after bilateral cryptorchidism. Horm Res. 2001;55:28-32.

Pastuszak AW, Wang R. Varicocele and testicular function. Asian J Androl. 2015;17:659-67.

Shin D, Lemack GE, Goldstein M. Induction of spermatogenesis and pregnancy after adult orchiopexy. J Urol. 1997;158:2242.

Stuart AL, Schoor R, Caroppo E, El Hanbly S, Ross L, Niederberger C. Evaluation of men with unilateral or bilateral undescended testes: Does age of correction make a difference? Fert Steril. 2003; 80(Suppl 3):4-5.

Vernaeve V, Krikilion A, Verheyen G, Van Steirteghem A, Devroey P, Tournaye H. Outcome of testicular sperm recovery and ICSI in patients with non-obstructive azoospermia with a history of orchidopexy. Hum Reprod. 2004;19:2307-12. 